\title{
Fatty acid transport and fatty acid-binding proteins
}

\author{
BY JACQUES H. VEERKAMP \\ Department of Biochemistry, University of Nijmegen, PO Box 9101, 6500 HB Nijmegen, \\ The Netherlands
}

\section{Transport des acides gras et protéines de liaison des acides gras}

\begin{abstract}
RÉSUMÉ
Les protéines de liaison ou de transfert des acides gras sont présentes dans les fluides intra- et extra-cellulaires de la plupart des organismes. Elles jouent un rôle dans le transport ou le ciblage des acides gras, mais peuvent également agir en interaction avec différent processus par la modulation de la concentration de la liaison libre. Quelques protéines de liaison des acides gras sont assez spécifiques, d'autres, telles que l'albumine sérique et la protéine cytoplasmique de liaison des acides gras (FABP) cystoliques du foie, sont associées par des liaisons hydrophobes. Certaines protéines lient également des acides gras sans fonction de transport, comme la protéine du choc thermique et les glutathion S-transférases ( $E C$ 2.5.1.18). La captation des acides gras dans les cellules peut se décrire par une séquence d'étapes qui peuvent être réversibles. Les étapes lentes, potentiellement limitantes du taux d'absorption n'ont pas été bien établies. La diffusion et la dissociation de l'albumine peuvent limiter la captation des acides gras, mais elles peuvent être facilitées dans certaines cellules par des récepteurs spécifiques de l'albumine ou par des modifications de la surface. La transcytose de l'albumine avec des acides gras liés à travers les cellules endothéliales peuvent moduler le transport des acides gras dans certains types de cellules telles que les cardiomyocytes. Cet acide gras libre peut facilement basculer (flip-flop) à travers la membrane plasmatique sous sa forme non ionisée. La preuve de l'implication d'une protéine liée aux acides gras de la membrane plasmatique dans l'absorption des acides gras a cependant été obtenue pour un grand nombre de types de cellules avec des données cinétiques et de couplage, l'isolation de protéines, et l'inhibition de l'absorption par des inhibiteurs et des anticorps. La masse moléculaire, l'identité, la structure tertiaire et le mécanisme d'action de ces protéines sont encore mal définies. Les FABP cytoplasmiques ont été bien caractérisées. Ce sont des protéines 14-15 kDa constituées de 127-133 acide aminés avec une structure $\beta$-clam. Sept types ont été identifiés avec une identité d'acide aminé de $25-70 \%$, avec une modification de charge de surface et une distribution de tissu caractéristique. Le type FABP du foie n'a, contrairement aux autres types, aucune spécificité de liaison, et est présent dans le foie, l'intestin et le rein. Le type du coeur est le type le plus répandu. Les types du foie et du coeur diffèrent dans leur affinité pour les acides gras différentes longueurs de chaîne, et l'étendue de l'insaturation. Le contenu du tissu du type FABP hépatique est davantage susceptible de variations physiologiques. Les FABP interviennent dans le transport de la membrane plasmatique vers les organites cellulaires comme on peut le conclure des expériences de transport avec marquage par photo-affinité et des incubations de FABP avec des membranes modèles et naturelles, et
\end{abstract}


dans un système cytosolique. Les acides gras liés au FABP sont captés par les mitochondries et oxydées. Les FABP peuvent réguler les concentrations d'acides gras libres cellulaires, et ainsi influencer le métabolisme des lipides, les récepteurs, les enzymes et les canaux ioniques. Les acides gras, et, indirectement, les FABP modulent l'expression des gènes qui interviennent dans la différentiation et la lipogenèse dans les adipocytes et dans la lipogenèse et la prolifération péroxisomale dans le foie. Ceci inclut les gènes FABP. La signification physiologique des différents types de FABP dans des tissus et des cellules spécifiques est inconnue. Pour le type FABP du foie, une fonction de transporteur universel apparaît probable, de même pour le transport des eicosanoïdes, des lysophospholipides, du hème et des hormones stéroïdes. Une protéine de liaison acyl-CoA spécifique (ACBP) de $10 \mathrm{kDa}$ et de structure identique est présente dans le cytoplasme de différents tissus. Il est possible que l'ACBP régule le métabolisme et l'action de l'acyl-CoA et le protège contre les hydrolases. A ce jour, il n'a pas été détecté de déficiences primaires ni de mutants structurels des FABP et de l'ACBP.

Fatty acids are essential components for every living cell, either as a source of energy by their oxidation in mitochondria or peroxisomes, or as a precursor for the synthesis of membrane lipids or lipid mediators. Some cells are able to synthesize fatty acids, others are completely dependent on supply by the blood. Uptake of fatty acids from the lumen contents of the intestine into enterocytes takes place after lipolytic action of pancreatic lipase ( $E C$ 3.1.1.3) and micellar solubilization. After absorption fatty acids are incorporated into triacylglycerols and phospholipids and secreted in chylomicrons. In the blood plasma fatty acids are transported either non-covalently bound to albumin or esterified in triacylglycerols of chylomicrons and VLDL. The fatty acids are distributed between intestine, liver and adipose tissue as fatty acid-delivering tissues and liver, heart, skeletal muscle, adipose tissue, kidney and other peripheral tissues as fatty acid-utilizing or -storing tissues.

The usual long-chain fatty acids are very insoluble in an aqueous medium (Vorum et al. 1992) and at physiological $\mathrm{pH}$ are present in acid-soap lamellar aggregates (Cistola et al. 1988). Therefore, they bind in vivo to membranes and to fatty acid-binding proteins. These molecules are present in intra- and extracellular fluids. They play a role in the transport or targeting of fatty acids, but may also interact with various cellular processes by modulation of the free fatty acid concentration. Some proteins which have no clear transfer function also bind fatty acids: e.g. $\beta$-lactoglobulin, heat-shock protein and glutathione S-transferase ( $E C$ 2.5.1.18). Some fatty acid-binding proteins are rather specific, but others such as serum albumin, $\alpha$-fetoprotein and liver cytoplasmic fatty acid-binding proteins (FABP) also bind other hydrophobic ligands. Serum albumin has three high-affinity, primary binding sites for long-chain fatty acids, established by ${ }^{13} \mathrm{C}$ NMR studies. The exchange between these sites has a half time $\left(t_{1 / 2}\right)$ longer than $66 \mathrm{~ms}$. The maximum binding capacity is about $10 \mathrm{~mol} / \mathrm{mol}$, but under physiological conditions, it is usually $2 \mathrm{~mol} / \mathrm{mol}$ or less. Comparative-binding studies on native albumin and three large fragments with ${ }^{13} \mathrm{C}$-labelled fatty acids revealed the location of two primary fatty acid-binding sites on the carboxyl-terminal domain and one primary site on the amino-terminal half (Hamilton et al. 1991). The secondary sites are assigned to the middle domain. For octanoic and decanoic acids the highest affinity binding sites appear to be structurally different from one another (Kenyon \& Hamilton, 1994). 


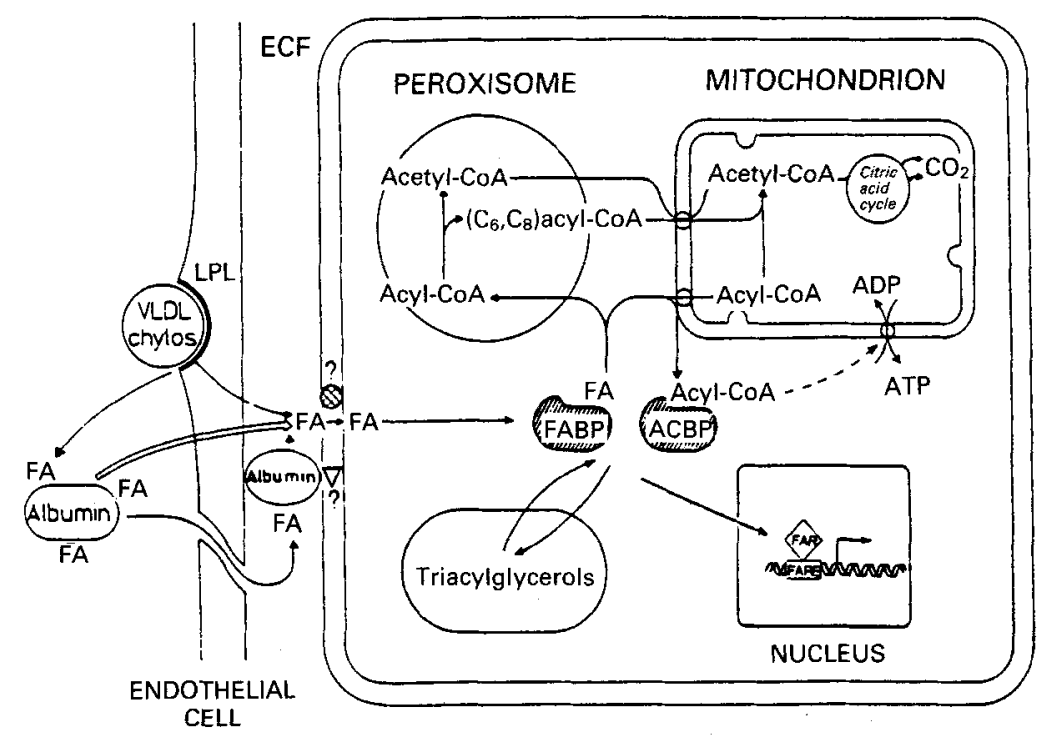

Fig. 1. Schematic representation of the fatty acid transfer from blood to cellular organelles. FABP, fatty acid-binding protein; ACBP, acyl-CoA-binding protein; FA, fatty acid; VLDL, very low density lipoproteins; chylos, chylomicrons; ECF, extracellular fluid; FAR, putative FA receptor; FARE, putative FA receptor element; plasma membrane FABP; $\nabla$, albumin receptor.

Triacylglycerols in chylomicrons and VLDL are hydrolysed by lipoprotein lipase ( $E C$ 3.1.1.34) in the capillaries and, thus, may contain also, transiently, fatty acids, especially at lower pH (Spooner et al. 1988) and under some pathological conditions such as hypoalbuminaemia, hyperlipaemia and diabetes. Redistribution of lipolyticallygenerated fatty acid from the chylomicron surface to the cell membrane may be driven by the predominant area of the cell membrane surfaces (Spooner et al. 1990). Albumin may exert an intermediary carrier function in the redistribution process.

Fatty acid uptake into the cell can be described by a sequence of steps, which may be reversible (Weisiger, 1993). Fig. 1 gives a schematic overview of the route of fatty acids from blood to cellular organelles; it shows also some of their interactions. Dissociation from albumin may limit fatty acid uptake (Daniels et al. 1985; Hamilton, 1989). The partitioning of fatty acids depends on the relative affinities of binding sites on albumin and cell plasma membranes. The presence of albumin receptors on hepatocytes is equivocal, but they have been found on endothelial cells, lymphocytes and probably cardiomyocytes (for references, see Veerkamp \& Maatman, 1995). Transcytosis may be important for transport of albumin and its ligands across the capillary endothelial lining of heart, lung and adipose tissue (Antohe et al. 1993). Albumin-fatty acid interaction (binding affinity, dissociation rate) could be changed by the cell surface, and in this way increase the uptake of unbound ligand. Albumin may be important in reducing the effective depth of the unstirred water layer and in permitting the diffusion barrier to conform to the microvilli of hepatocytes, thus increasing the effective surface area 
available for diffusion of the fatty acid (Weisiger et al. 1991). In fetal plasma $\alpha$-fetoprotein and fetuin may substitute for albumin.

Fatty acid transport across the plasma membrane is presumably a passive process determined by simple diffusion and partition. All fatty acids from octanoic up to arachidonic acid exhibit rapid transbilayer movement $\left(t_{1 / 2}<1 \mathrm{~s}\right)$ via the non-ionized form (Kamp \& Hamilton, 1993). The membrane composition and the $\mathrm{pH}$ of the medium influence the apparent dissociation constant of the fatty acid in the membrane and in this way the ratio for ionized:non-ionized species (Hamilton, 1994). Dissociation of mediumand long-chain fatty acids from albumin takes place on the time-scale of seconds (Daniels et al. 1985) or faster (Kamp \& Hamilton, 1992) dependent on the affinity of the binding site and, thus, fatty acid:albumin ratio. The exchange of oleic and palmitic acid between albumin and phospholipid vesicles is fast $(k<1 / \mathrm{s}$; Kamp \& Hamilton, 1992). Acidic pH increases the proportion of fatty acid bound to phospholipid membranes in the presence of albumin (Hamilton \& Cistola, 1986). With increasing fatty acid chain length the $t_{1 / 2}$ of residence time of the fatty acid in a binding site on albumin increases and the rate of equilibration between albumin and model membranes decreases (Hamilton, 1989). The transfer rate of octanoic acid from albumin to vesicles is $10^{3}$ higher than that of common dietary long-chain fatty acids. This may be important for the utilization of medium-chain fatty acids.

The data on fatty acid transfer in model systems and on fatty acid uptake by various cell types (for references, see Veerkamp \& Maatman, 1995) indicate that additional membrane fatty acid-binding proteins are not essential. Evidence for these proteins has been based on the kinetics of fatty acid uptake, the binding of fatty acids to isolated plasma membranes, the action of proteases and inhibitors, the isolation of such proteins and the inhibition of fatty acid uptake by antibodies against an isolated liver membrane protein (for references, see Sorrentino \& Berk, 1993; Veerkamp \& Maatman, 1995). Cell types studied were hepatocytes, cardiomyocytes, adipocytes, enterocytes, hepatoma cells, and keratinocytes. The experimental results may be interpreted differently and they have been disputed by other investigators. The rat adipocyte membrane protein suggested to be implicated in binding or transport of long-chain fatty acid (Abumrad et al. 1993) is an acylated surface-membrane protein related to CD36 (Jochen \& Hays, 1993).

Recent findings indicate that the fatty acid uptake is determined by the balance between the rate of diffusion of fatty acids in the cytoplasm and the kinetics of their subsequent metabolic conversions. Intracellularly, specific cytoplasmic FABP have been detected in various tissues of vertebrates and some invertebrates. The fatty acid distribution between blood plasma (extracellular fluid) and cytoplasm may be dependent on the partition between albumin, plasma membrane and FABP. The role of FABP in fatty acid uptake was theoretically discussed for hepatocytes and cardiomyocytes (for references, see Veerkamp \& Maatman, 1995). A role for FABP in fatty acid release from the plasma membrane is not likely, since their off rate from phospholipid membranes is high (Kamp \& Hamilton, 1992). Kinetic studies of labelling FABP from different cell types with radiolabelled fatty acid analogues (Waggoner et al. 1991) and many studies with model and natural membranes in combination with various FABP preparations (for references, see Veerkamp \& Maatman, 1995) have demonstrated the fatty acid transfer function of FABP. Evidence for this function could be obtained in a model cytosol system (Stewart et al. 1991). FABP may influence the flux of the fatty acid by diffusion, by reducing membrane binding (Luxon \& Weisiger, 1993). 
Table 1. Occurrence of fatty acid-binding protein (FABP) types

\begin{tabular}{ll}
\hline \hline FABP type & Tissue* \\
\hline Liver $\dagger$ & Liver $\dagger$, intestine $\dagger$, kidney $\dagger$, stomach \\
Intestinal & Intestine $\dagger$, stomach \\
Heart & Heart $\dagger$, kidney $\dagger$, skeletal muscle $\dagger$, aorta $\dagger$, adrenals $\dagger$, placenta $\dagger$, brain $\dagger$, testes, \\
& ovary, lung, mammary gland, stomach \\
Adipocyte $\S$ & Adipose tissue $\dagger$ \\
Myelin $\|$ & Peripheral nervous system $\dagger$, spinal cord \\
Ileal $\uparrow$ & Intestine $\dagger$, ovary, adrenals, stomach \\
Epidermal & Skin $\dagger$ \\
\hline \hline
\end{tabular}

* The indication of a FABP type in a tissue does not mean its presence in all cell types of that tissue; the FABP type may be limited to specific cells or may be present at certain developmental stages.

$\dagger$ Evidence was obtained both by protein and mRNA analysis.

$\Varangle$ Previously termed $\mathrm{Z}$-protein or aminoazo dye-binding protein $\mathrm{A}$.

$\S$ Also named adipocyte lipid-binding protein or initially $\mathrm{p} 422$ or $\mathrm{aP}_{2}$.

Also named myelin $\mathrm{P}_{2}$ protein or $\mathrm{PMP}_{2}$.

II Also named ileal lipid-binding protein and originally gastrotropin.

\section{STRUCTURE OF FATTY ACID-BINDING PROTEINS AND ACYL-COA-BINDING PROTEIN (ACBP)}

Seven types of cytoplasmic FABP have been well identified up to now (Veerkamp \& Maatman, 1995). They are 14-15 kDa proteins of 127-133 amino acids and are named after the first tissue of isolation or identification (Table 1). The main fatty acidmetabolizing tissues contain distinct types of FABP. The heart type of FABP is the most universal one. Some tissues contain more types, either in different cell types (kidney, stomach) or in the same cell (enterocyte). All these proteins bind one molecule of fatty acid (except the liver type of FABP, which may bind two molecules). They differ in primary structure, chromosomal localization and regulation of their genes and the response of their concentration to changes of physiological or pharmacological conditions (Veerkamp et al. 1993; Veerkamp \& Maatman, 1995). Their amino acid identity is $25-70 \%$ and their surface charge differs considerably. Structurally they are characterized by ten antiparallel $\beta$-strands linked by short reverse turns. The first two $\beta$-strands are connected by two $\alpha$-helices. The $\beta$-strands are organized to form two $\beta$-sheets, each constituting half a clam shell with the strands in each half oriented nearly orthogonally to one another (Sacchettini et al. 1988; Zanotti et al. 1992; Young et al. 1994). Differences in amino acid composition, volume distribution of the binding pocket and solvent localization influence the binding and the conformation of the ligand. The fatty acid has an extended, slightly bent conformation in intestinal and adipocyte FABP, but a U-shaped conformation in heart (muscle) and myelin FABP. Electrostatic interactions and a H-bonding network with the carboxyl group are involved in fatty acid binding by most FABP types. Liver and ileal FABP may differ in this respect from the other types, but this has to be more precisely established. The location of the fatty acid in liver FABP appears to be closer to the surface than that in intestinal FABP, based on ${ }^{13} \mathrm{C} N \mathrm{NM}$ data (Cistola et al. 1989).

The ligand specificity has been well studied only for liver and heart (muscle) types of FABP. In contrast to the other types of FABP, liver FABP shows binding of a large 
variety of hydrophobic ligands, including acyl-CoA, acylcarnitine, eicosanoids, lysophospholipids, haem, and some steroid hormones and peroxisomal proliferators (Veerkamp et al. 1993; Maatman et al. 1994). Ileal FABP has a higher affinity for bile acids than for fatty acids (Sacchettini et al. 1990). In a recent comparative study we investigated the binding characteristics of human liver and muscle FABP for fatty acids of different chain-length and different number and nature of double bonds (Maatman et al. 1994). $\mathrm{C}_{12}-\mathrm{C}_{18}$ saturated fatty acids and $\mathrm{C}_{16}-\mathrm{C}_{24}$ unsaturated fatty acids bind well to liver FABP, whereas muscle FABP has a preference for unsaturated fatty acids, especially $\mathrm{C}_{18}$ (Fig. 2). Stearic, oleic and elaidic acids are bound in the internal cavity of muscle FABP in the same arched conformation (Young et al. 1994).

In the cytoplasm of nearly all cell types of mammals a specific ACBP of $10 \mathrm{kDa}$ (eighty-six amino acids) is present (Knudsen et al. 1993). In contrast to FABP its structure is identical in all tissues of one organism. Its concentration is one order of magnitude lower than that of FABP, but its affinity to long-chain acyl-CoA is very high (Rasmussen et al. 1994). The molecule is a four-helix protein organized in a bowl-like structure with the binding site for acyl-CoA in the core (Kragelund et al. 1993). The protein and acyl-CoA associate by a combination of non-polar and electrostatic interactions. Whereas the whole fatty acid is enclosed by FABP, the CoA head of acyl-CoA covers one side of the acyl chain from the solvent, when this ligand is bound to ACBP. ACBP shows a clear preference for $\mathrm{C}_{14}-\mathrm{C}_{22}$ saturated and unsaturated acyl-CoA esters (Rosendal et al. 1993). The $3^{\prime}$-phosphate on the ribose moiety of CoA is essential for binding.

\section{FUNCTIONS OF FATTY ACID-BINDING PROTEIN AND ACYL-COA-BINDING PROTEIN}

The roles of FABP and ACBP in the cell are to a large extent comparable and additive. They may mediate intermembrane transfer for their respective ligands, create a cytoplasmic pool and modulate their effects on vital cellular systems such as enzymes, membranes, transport systems, and receptors (Fig. 1). Conclusive evidence for these functions, however, is lacking. The functional significance of distinct FABP types in different cells is not even known. The role of these proteins in intermembrane transfer has been demonstrated in model systems either by direct assay of ligand transport or after conversion by metabolically-active systems such as mitochondria, peroxisomes or microsomes (Veerkamp et al. 1991; Rasmussen et al. 1994). FABP-bound fatty acids and ACBP-bound acyl-CoA esters are both well utilized by mitochondria for oxidation or by microsomes for lipid synthesis. A correlation was found between the FABP content and the fatty acid oxidation capacity of some rat tissues (Veerkamp \& Van Moerkerk, 1993). The endogenous fatty acid composition of liver FABP is strongly influenced by dietary fatty acid composition (DeMarco et al. 1993).

It is not likely that FABP-bound fatty acids can directly function as substrate for acyl-CoA synthase ( $E C \quad 6.2 .1 .13$ ) or other fatty acid-metabolizing enzymes. The membrane-associated fatty acid appeared to be the pool of substrate interacting with the microsomal acyl-CoA ligase when palmitate was added as a component of phospholipid vesicles to rat liver microsomes (Noy \& Zakim, 1985); FABP addition inhibited the reaction. FABP may influence, by modulation of fatty acid or acyl-CoA availability, the activity of microsomal and mitochondrial acyl-CoA synthase and many acyl-CoA 
(a) Displacement of $\left[1-{ }^{14} \mathrm{C}\right]$ oleic acid from liver FABP

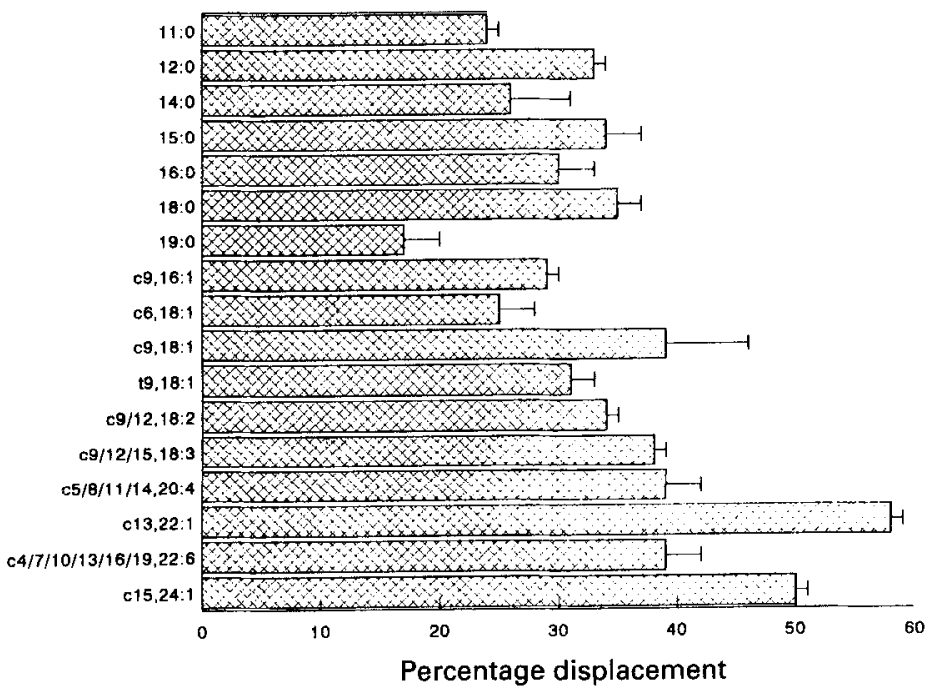

(b) Displacement of [1-14 C]oleic acid from muscle FABP

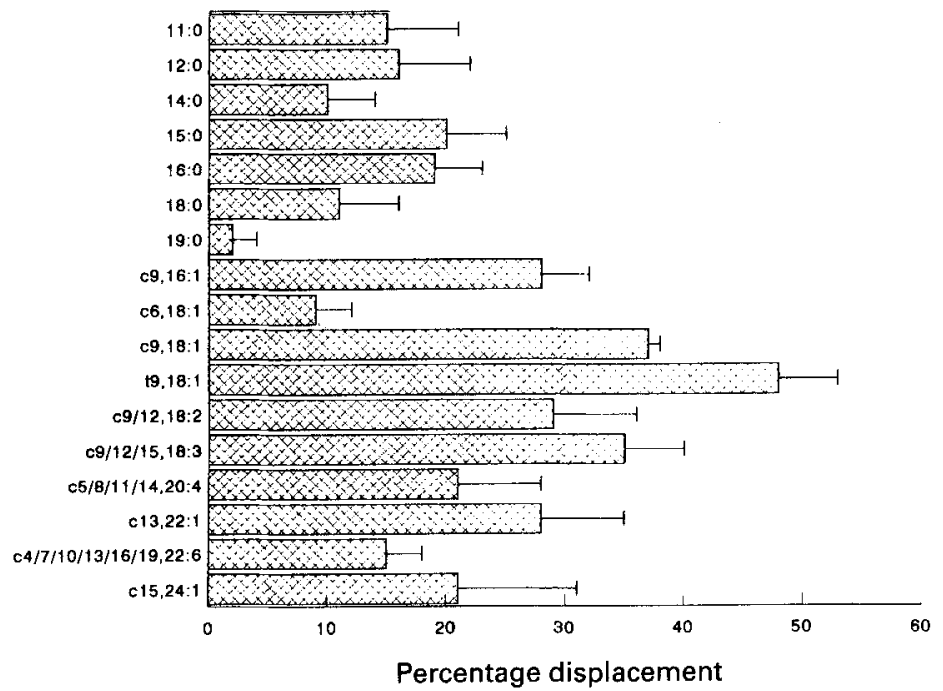

Fig. 2. Displacement of $\left[1-{ }^{14} \mathrm{C}\right]$ oleic acid from (a) human liver fatty acid-binding protein (FABP) and (b) human muscle FABP by various fatty acids. Displacement is given as the percentage of $\left[{ }^{14} \mathrm{C}\right]$ oleic acid binding in the absence of competitor. Concentrations were $0.2 \mu \mathrm{M}$-liver FABP or $0.28 \mu \mathrm{M}$-muscle FABP, 1 $\mu \mathrm{M}-\left[{ }^{14} \mathrm{C}\right]$ oleic acid and $1 \mu \mathrm{M}$-competitor. Binding was determined by the Lipidex procedure. Values are means and standard deviations represented by vertical bars for four experiments. 
acyltransferases. The latter property may especially concern the liver type of FABP, since other types of FABP have little affinity for acyl-CoA. ACBP effectively opposes the product feedback inhibition of the long-chain acyl-CoA synthetase by acyl-CoA sequestration (Rasmussen et al. 1993). Cooperativity exists between FABP, which solubilizes the fatty acid and loosely-bound acyl-CoA, and ACBP which desorbs acyl-CoA on the leaving site of acyl-CoA synthase. ACBP inhibits incorporation of acyl-CoA into triacylglycerols, but not into phospholipids of rat liver microsomes (Rasmussen et al. 1994).

FABP and ACBP efficiently extract fatty acids and acyl-CoA respectively from membranes. In contrast to fatty acids, acyl-CoA esters show a slow transbilayer movement (Boylan \& Hamilton, 1992). Thus, their utilization will be from the outer leaflet of the membrane, to which they are exposed. ACBP protects the cytoplasmic acyl-CoA esters against degradation by acyl-CoA hydrolases (Rasmussen et al. 1994). FABP-bound fatty acids together with the very low free fatty acid concentration form a diffusible pool of fatty acids available in the cytoplasm.

Fatty acids, their CoA and carnitine esters and derived compounds such as lysophospholipids and eicosanoids, influence directly or indirectly various cellular processes by their interaction with enzymes, receptors, ion channels, membranes or genes (Veerkamp et al. 1991, 1993). FABP and ACBP modulate these interactions by their effects on the synthesis, transport and availability of the free ligand. They may even have a protective role in conditions of increased release of fatty acids and/or acyl-CoA such as starvation, in liver, and ischaemia in heart, kidney, liver, and other tissues. ACBP strongly attenuates the inhibition by long-chain acyl-CoA of acetyl-CoA carboxylase (EC 6.4.1.2) and mitochondrial adenine nucleotide translocase (Fig. 1; Rasmussen et al. 1993). FABP was reported to have similar effects on fatty acid inhibition of certain enzymes (for references, see Paulussen \& Veerkamp, 1990). The possible influence of fatty acids and eicosanoids on cellular receptors, signal transduction-involved enzymes and ion channels, accentuate the significance of FABP in the cell (Veerkamp et al. 1993). FABP may improve the efficiency of the utilization of unsaturated fatty acids in the formation, integrity and fluidity of cell membranes that are involved in cell growth, morphology and survival (Keler \& Sorof, 1993).

The involvement of fatty acids in gene regulation in adipocytes, liver, lymphocytes and breast cancer cells (for references, see Veerkamp et al. 1993; Amri et al. 1994; Jump et al. 1994; Veerkamp \& Maatman, 1995) suggests a possible role of FABP, analogous with that of cellular retinoic acid-binding proteins in regulating the concentration of fatty acid or fatty acyl metabolite that can interact with a nuclear receptor protein, acting as trans factor. Polyunsaturated fatty acids suppress the fatty-acid synthase ( $E C$ 2.3.1.85) gene, but only in liver (Clarke \& Abraham, 1992). Coordinately, they regulate the expression of several enzymes involved in carbohydrate and lipid metabolism (Jump et al. 1994). Liver FABP was suggested to be involved in shuttling specific polyunsaturated fatty acids to a nuclear polyunsaturated fatty acid-binding receptor (Clarke \& Jump, 1993). This ligand-activated protein would inhibit the transcription of the fatty acid synthase gene. Fatty acids are like many peroxisome proliferators and hexadecanedioic acid activators of peroxisomal-proliferator-activated receptors (PPAR; Göttlicher et al. 1993). These receptors represent, therefore, the first examples of higher eukaryotic transcription factors, that are activated by nutrients (Keller \& Wahli, 1993). PPAR activators may originate from, or be controlled by, FABP (Veerkamp \& Maatman, 1995). 
Fatty acids in the medium potentiate the induction of expression of mRNA of acyl-CoA synthase and adipocyte FABP in cultured pre-adipocytes (Abumrad et al. 1991; Amri et al. 1991a , 1994; Distel et al. 1992; Grimaldi et al. 1992) and are necessary to maintain the expression of the FABP gene in adipocytes in glucose-free medium (Abumrad et al. 1991; Amri et al. 1991b). Thus, the expression of the adipocyte FABP was correlated with the availability of fatty acid from endogenous or exogenous source (Amri, 1991b). This activation of the adipocyte FABP gene by fatty acids was not observed in non-adipose cells (Amri et al. 1991a; Distel et al. 1992). The role of FABP in lipogenesis and lipolysis in adipocytes in vivo is not known. ACBP induction by insulin is slightly delayed compared with induction of lipogenic enzymes (Hansen et al. 1991). ACBP is presumably not directly involved in acyl-CoA transport from the acyl-CoA ligase to the acyl transferases for glycerolipid synthesis, since these enzymes are all located in the endoplasmic reticulum.

\section{PHYSIOLOGICAL, PHARMACOLOGICAL AND PATHOLOGICAL EFFECTS ON FATTY ACID-BINDING PROTEINS AND ACYL-COA-BINDING PROTEIN}

Table 2 shows the response of various types of FABP and/or FABP mRNA content to various conditions. Differentiation of adipocytes in culture is accompanied by an increase in the concentrations of adipocyte FABP and ACBP (Bernlohr et al. 1984; Abumrad et al. 1991; Hansen et al. 1991). The content of FABP in adipose tissue was increased by $50 \%$ with a high-fat diet (Veerkamp \& Van Moerkerk, 1993). Streptozotocin-diabetes markedly decreased the levels of adipocyte FABP and its mRNA in rat adipose tissue (Melki \& Abumrad, 1993). These changes are, however, slower than changes in fatty acid synthase mRNA and disappearance of lipid and may relate to dedifferentiation.

Table 2. Conditions which influence fatty acid-binding protein (FABP) concentrations in the rat

\begin{tabular}{|c|c|c|c|c|}
\hline & Liver & (Heart) muscle & Adipose tissue & Intestine \\
\hline Differentiation & $\uparrow$ & $\uparrow$ & $\uparrow$ & $\uparrow$ \\
\hline Postnatal development & $\uparrow$ & $\uparrow$ & & $\uparrow$ \\
\hline Starvation & - & - & & $\uparrow$ \\
\hline High-fat diet ( $40 \%$ energy) & $\uparrow$ & - & $\uparrow$ & $\uparrow *$ \\
\hline Type of fat $(100 \mathrm{~g} / \mathrm{kg})$ & - & - & & \\
\hline \multicolumn{5}{|l|}{ Hormones: } \\
\hline Oestrogens & $\uparrow$ & & & \\
\hline Testosterone & $\downarrow$ & $\uparrow$ & & \\
\hline Glucocorticoids & $\downarrow$ & - & & \\
\hline \multicolumn{5}{|l|}{ Drugs: Peroxisomal } \\
\hline Proliferators & $\uparrow$ & - & & $\uparrow *$ \\
\hline Cholestyramine & $\downarrow$ & - & & \\
\hline Alcohol & $\uparrow$ & & & \\
\hline Exercise (special cases) & & $\uparrow$ & & \\
\hline Diabetes & $\downarrow$ & $\uparrow$ & $\downarrow$ & \\
\hline
\end{tabular}

$\downarrow$, Decrease; $\uparrow$, increase; -, no change.

$*$ Only the liver type of FABP. 
Condition

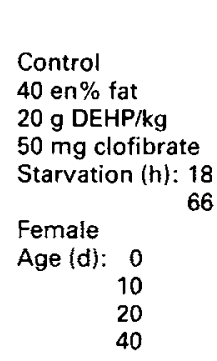

(a) Palmitate oxidation capacity

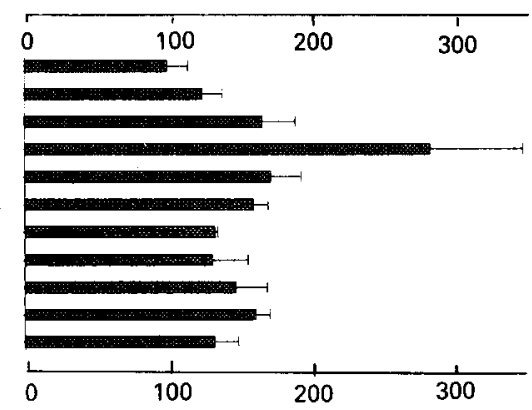

(b) FABP content

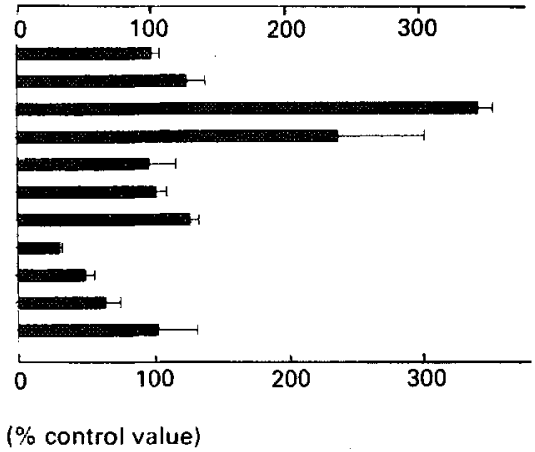

Fig. 3. Effect of various physiological conditions on $(a)$ palmitate oxidation capacity and $(b)$ fatty acid-binding protein (FABP) content of rat liver. Values are given as percentages of the control (male, fed, 70-d-old rat) value and are means and standard deviations represented by vertical bars for four to ten animals. DEHP, di(2-ethylhexyl)phthalate.

Differentiation and postnatal development of hepatocytes are associated with an increase in liver FABP content together with an increase in fatty acid oxidation before weaning and in lipogenic capacity after weaning (Veerkamp \& Van Moerkerk, 1993; Girard et al. 1994). High-fat diets (35-57\%) increased the FABP content of rat liver (Haq \& Shrago, 1985; Malewiak et al. 1988; Veerkamp \& Van Moerkerk, 1993). The type of dietary fat (up to 10\%) had only a slight or no effect on the FABP content of rat liver (DeMarco et al. 1993; Veerkamp \& Van Moerkerk, 1993). Peroxisomal proliferators increase the liver FABP content in liver and intestine of rodents together with fatty acid oxidation, especially in peroxisomes (for references, see Veerkamp \& Maatman, 1995). The transcription of genes of several enzymes involved in peroxisomal oxidation, of microsomal cytochrome P450 4Al enzymes, and of FABP is upregulated. In cultured hepatocytes an increase in FABP, ACBP and peroxisomal $\beta$-oxidation was observed after clofibrate treatment (Van den Heuvel et al. 1993).

Hormones influence, among many other metabolic factors, FABP content in liver tissue. Oestrogens, insulin, growth hormone and thyroid hormone increase, while testosterone and glucocorticoids decrease liver FABP (Nakagawa et al. 1994; Veerkamp \& Maatman, 1995). Streptozotocin-diabetes decreased the liver FABP content, but starvation had little influence. Comparison of changes in FABP, fatty acid oxidation (Fig. 3) and synthesis and fatty acid incorporation into triacylglycerols and phospholipids under various conditions suggests that FABP is only one of the rate-determining factors of fatty acid metabolism (Ockner et al. 1979; Veerkamp \& Van Moerkerk, 1993).

Heart and skeletal muscle show a concomitant postnatal development of fatty acid oxidation and FABP content (Veerkamp \& Van Moerkerk, 1993). Many conditions such as percentage and type of dietary fat, starvation, treatment with peroxisomal proliferators, sex and age (5-25 months) had no effect on fatty acid oxidation capacity and FABP content of rat heart and skeletal muscle. Swim training did not influence FABP content of rat heart, soleus and quadriceps muscles, but electrostimulation and treadmill running increased the FABP content of tibialis anterior and plantaris muscle respectively (Kaufmann et al. 1989; Degens et al. 1993). Streptozotocin-diabetes and 
testosterone treatment increased the FABP content of rat heart and slow-twitch skeletal muscle (Van Breda et al. 1992; Carey et al. 1994; Glatz et al. 1994). The increase in FABP content of heart and skeletal muscle may be related to the increased fatty acid uptake and oxidation under the latter conditions. Glucocorticoid treatment had no effect on FABP content of rat diaphragm (Veerkamp \& Van Moerkerk, 1993).

Hypoxia of rats for 3 weeks decreased the plasma free fatty acids and the FABP content of heart. Intralipid treatment increased the plasma free fatty acid by $100 \%$, but had no effect on heart FABP (Garnier et al. 1993). These findings suggest that plasma fatty acid concentrations are not controlling heart FABP content.

In the intestine the liver and intestinal types of FABP show similar temporal and regional patterns of expression (for references, see Veerkamp et al. 1993; Veerkamp \& Maatman, 1995). A crypt-to-villus gradient is present for both FABP types. The level of the proteins and their mRNAs vary also along the cephalo-caudal axis of the gut, with the highest concentration in the jejunum. The significance of the presence of these two FABP types in the enterocyte is not clear. Since intestinal mucosa takes up fatty acids not only from the intestinal lumen, but also from the plasma pool, Alpers et al. (1984) suggested that intestinal FABP is involved in transfer of luminal fatty acids for triacylglycerol synthesis and liver FABP in transfer of plasma-originating fatty acids for oxidation or phospholipid synthesis. Cistola et al. (1989) suggested that intestinal FABP would transport only (luminal or plasma) fatty acids, and liver FABP also transported other ligands such as monoacylglycerols, lysophospholipids and acyl-CoA esters. The distinct roles of both FABP types in the intestine are also indicated by their different responses to physiological and pharmacological changes. Clofibrate treatment increased the content of liver FABP, but not that of intestinal FABP in rat jejunum (Bass et al. 1985). A $450 \mathrm{~g}$ fat $/ \mathrm{kg}$ diet increased the mRNA of liver FABP, but not of intestinal FABP (Besnard et al. 1991). Sex did not influence the concentration of either type of FABP in the jejunum (Bass et al. 1985) but starvation for 3 d doubled the mRNA concentration for both types (Besnard et al. 1991).

Up to now primary deficiencies or structural mutants of FABP or ACBP have not been described. Secondary deficiencies and use of FABP as a cell integrity marker have been reported (see Veerkamp et al. 1993). Release of FABP was observed in myocardial infarction, liver disease and experimental ischaemia of heart and intestine. Expression of epidermal FABP was very high in psoriasis, a disease characterized by abnormal epidermal differentiation, but low in normal skin (Madsen et al. 1992; Siegenthaler et al. 1993). This suggests an altered transport or metabolism of fatty acids in psoriatic skin.

Diabetes had divergent effects on FABP contents of rat adipose tissue, liver, heart and skeletal muscle, as discussed previously. Indications have been obtained for a genetic linkage on chromosome 4 between the human intestinal FABP gene locus and a locus related to insulin action (Mitchell et al. 1993; Prochazka et al. 1993). No specific metabolic disturbances have been found related to FABP deficiency.

In conclusion, FABP may function as intracellular fatty acid carriers, like albumin extracellularly. In addition, they may modulate fatty acid concentration in the cytoplasm and in this way fatty acid metabolism and their effects on various cellular systems. ACBP regulates the acyl-CoA pool. The presence and function of plasma membrane fatty acid-binding proteins and the functional significance of the distinct FABP types are unclear. 


\section{REFERENCES}

Abumrad, N. A., Forest, C. C., Regen, D. M. \& Sanders, S. (1991). Increase in membrane uptake of long-chain fatty acids during preadipocyte differentiation. Proceedings of the National Academy of Sciences USA 88, 6008-6012.

Abumrad, N. A., Raafat El-Maghrabi, M., Amri, E.-Z., Lopez, E. \& Grimaldi, P. A. (1993). Cloning of a rat adipocyte membrane protein implicated in binding or transport of long-chain fatty acids that is induced during preadipocyte differentiation. Journal of Biological Chemistry 268, 17665-17668.

Alpers, D. H., Strauss, A. W., Ockner, R. K., Bass, N. M. \& Gordon, J. I. (1984). Cloning of a cDNA encoding rat intestinal fatty acid binding protein. Proceedings of the National Academy of Sciences USA 81, 313-317.

Amri, E.-Z., Ailhaud, G. \& Grimaldi, P. (1991a). Regulation of adipose cell differentiation. II. Kinetics of induction of the aP2 gene by fatty acids and modulation by dexamethasone. Journal of Lipid Research 32, 1457-1463.

Amri, E.-Z., Ailhaud, G. \& Grimaldi, P.-A. (1994). Fatty acids as signal transducing molecules: involvement in the differentiation of preadipose to adipose cells. Journal of Lipid Research 35, 930-937.

Amri, E.-Z., Bertrand, B., Ailhaud, G. \& Grimaldi, P. (1991b). Regulation of adipose cell differentiation. 1. Fatty acids are inducers of the aP2 gene expression. Journal of Lipid Research 32, 1449-1456.

Antohe, F., Dobrila, L., Heltianu, C., Simionescu, N. \& Simionescu, M. (1993). Albumin-binding proteins function in the receptor-mediated binding and transcytosis of albumin across cultured endothelial cells. European Journal of Cell Biology 60, 268-275.

Bass, N. M., Manning, J. A., Ockner, R. K., Gordon, J. I., Seetharam, S. \& Alpers, D. H. (1985). Regulation of the biosynthesis of two distinct fatty acid-binding proteins in rat liver and intestine. Journal of Biological Chemistry 260, 1432-1436.

Bernlohr, D. A., Angus, C. W., Lane, M. D., Bolanowski, M. A. \& Kelly, T. J. (1984). Expression of specific mRNAs during adipose differentiation: identification of an mRNA encoding a homologue of myelin P2 protein. Proceedings of the National Academy of Sciences USA 81, 5468-5472.

Besnard, P., Bernard, A. \& Carlier, H. (1991). Quantification des ARNm codant pour les fatty acid binding proteins (FABP) entérocytaires de rat: effet d'un régime hyperlipidique et du jeûne (Quantification of mRNA encoding rat enterocyte fatty acid-binding proteins (FABP): effect of a high-fat diet and starvation). Comptes Rendus de l'Académie des Sciences Paris 312, 407-413.

Boylan, J. G. \& Hamilton, J. A. (1992). Interactions of acyl-coenzyme A with phosphatidylcholine bilayers and serum albumin. Biochemistry 31, 557-567.

Carey, J. O., Neufer, P. D., Farrar, R. P., Veerkamp, J. H. \& Dohm, G. L. (1994). Transcriptional regulation of muscle fatty acid-binding protein. Biochemical Journal 298, 613-617.

Cistola, D. P., Hamilton, J. A., Jackson, D. \& Small, D. M. (1988). Ionization and phase behavior of fatty acids in water: application of the Gibbs phase rule. Biochemistry 27, 1881-1888.

Cistola, D. P., Sacchettini, J. C., Banaszak, L. J., Walsh, M. T. \& Gordon, J. I. (1989). Fatty acid interactions with rat intestinal and liver fatty acid-binding proteins expressed in Escherichia coli. A comparative ${ }^{13} \mathrm{C}$ NMR study. Journal of Biological Chemistry 264, 2700-2710.

Cistola, D. P., Small, D. M. \& Hamilton, J. A. (1987). Carbon 13 NMR studies of saturated fatty acids bound to bovine serum albumin. I. The filling of individual fatty acid binding sites. Journal of Biological Chemistry 262, 10971-10979.

Clarke, S. D. \& Abraham, S. (1992). Gene expression: nutrient control of pre- and posttranscriptional events. FASEB Journal 6, 3146-3152.

Clarke, S. D. \& Jump, D. B. (1993). Regulation of gene transcription by polyunsaturated fatty acids. Progress of Lipid Research 32, 139-149.

Daniels, C., Noy, N. \& Zakim, D. (1985). Rates of hydration of fatty acids bound to unilamellar vesicles of phosphatidylcholine or to albumin. Biochemistry 24, 3286-3292.

Degens, H., Veerkamp, J. H., Van Moerkerk, H. T. B., Turek, Z., Hoofd, L. J. C. \& Binkhorst, R. A. (1993). Metabolic capacity, fibre type area and capillarization of rat plantaris muscle. Effects of age, overload and training and relationship with fatigue resistance. International Journal of Biochemistry 25, 1141-1148.

DeMarco, A. C., Patterson, P. P., Cantrill, R. C. \& Horrobin, D. F. (1993). Modification of the fatty acid binding profile of liver fatty acid binding protein (L-FABP). Journal of Nutritional Biochemistry 4, 515-522.

Distel, R. J., Robinson, G. S. \& Spiegelman, B. M. (1992). Fatty acid regulation of gene expression. Journal of Biological Chemistry 267, 5937-5941. 
Garnier, A., Poizat, C., Keriel, C., Cuchet, P., Vork, M. M., De Jong, Y. F. \& Glatz, J. F. C. (1993). Modulation of fatty acid-binding protein content of adult rat heart in response to chronic changes in plasma lipid levels. Molecular and Cellular Biochemistry 123, 107-112.

Girard, J., Perdereau, D., Foufelle, F., Prip-Buus, C. \& Ferré, P. (1994). Regulation of lipogenic enzyme gene expression by nutrients and hormones. FASEB Journal 8, 36-42.

Glatz, J. F. C., Van Breda, E., Keizer, H. A., De Jong, Y. F., Lakey, J. R. T., Rajotte, R. V., Thompson, A., Van der Vusse, G. J. \& Lopaschuk, G. D. (1994). Rat heart fatty acid-binding protein content is increased in experimental diabetes. Biochemical and Biophysical Research Communications 199, 639-646.

Göttlicher, M., Demoz, A., Svensson, D., Tollet, P., Berge, R. K. \& Gustafsson, J.-A. (1993). Structural and metabolic requirements for activators of the peroxisome proliferator-activated receptor. Biochemical Pharmacology 46, 2177-2184.

Grimaldi, P. A., Knobel, S. M., Whitesell, R. R. \& Abumrad, N. A. (1992). Induction of aP2 gene expression by nonmetabolized long-chain fatty acids. Proceedings of the National Academy of Sciences USA 89, 10930-10934.

Hamilton, J. A. (1989). Medium-chain fatty acid binding to albumin and transfer to phospholipid bilayers. Proceedings of the National Academy of Sciences USA 86, 2663-2667.

Hamilton, J. A. (1995). ${ }^{13} \mathrm{C}$ NMR studies of the interactions of fatty acids with phospholipid bilayers, plasma lipoproteins, and proteins. In Carbon-13 NMR Spectroscopy, pp. 117-157 [N. Beckman, editor]. New York: Academic Press.

Hamilton, J. A. \& Cistola, D. P. (1986). Transfer of oleic acid between albumin and phospholipid vesicles. Proceedings of the National Academy of Sciences USA 83, 82-86.

Hamilton, J. A., Era, S., Bhamidipati, S. P. \& Reed, R. G. (1991). Locations of the three primary binding sites for long-chain fatty acids on bovine serum albumin. Proceedings of the National Academy of Sciences USA 88, 2051-2054.

Hansen, H. O., Andreasen, P. H., Mandrup, S., Kristiansen, K. \& Knudsen, J. (1991). Induction of acyl-CoA-binding protein and its mRNA in 3T3-L1 cells by insulin during preadipocyte-to-adipocyte differentiation. Biochemical Journal 277, 341-344.

Haq, R.-U. \& Shrago, E. (1985). Dietary and nutritional aspects of fatty acid binding proteins. Chemistry and Physics of Lipids 38, 131-135.

Jochen, A. \& Hays, J. (1993). Purification of the major substrate for palmitoylation in rat adipocytes: $\mathrm{N}$-terminal homology with CD36 and evidence for cell surface acylation. Journal of Lipid Research 34, 1783-1792.

Jump, D. B., Clarke, S. D., Thelen, A. \& Liimatta, M. (1994). Coordinate regulation of glycolytic and lipogenic gene expression by polyunsaturated fatty acids. Journal of Lipid Research 35, 1076-1084.

Kamp, F. \& Hamilton, J. A. (1992). pH gradients across phospholipid membranes caused by fast flip-flop of un-ionized fatty acids. Proceedings of the National Academy of Sciences USA 89, 11367-11370.

Kamp, F. \& Hamilton, J. A. (1993). Movement of fatty acids, fatty acid analogues, and bile acids across phospholipid bilayers. Biochemistry 32, 11074-11085.

Kaufmann, M., Simoneau, J.-A., Veerkamp, J. H. \& Pette, D. (1989). Electrostimulation-induced increases in fatty acid-binding protein and myoglobin in rat fast-twitch muscle and comparison with tissue levels in heart. FEBS Letters 245, 181-184.

Keler, T. \& Sorof, S. (1993). Growth promotion of transfected hepatoma cells by liver fatty acid binding protein. Journal of Cellular Physiology 157, 33-40.

Keller, H. \& Wahli, W. (1993). Peroxisome proliferator-activated receptors. A link between endocrinology and nutrition? Trends in Endocrinology and Metabolism 4, 291-296.

Kenyon, M. A. \& Hamilton, J. A. (1994). ${ }^{13}$ C NMR studies of the binding of medium-chain fatty acids to human serum albumin. Journal of Lipid Research 35, 458-467.

Knudsen, J., Mandrup, S., Rasmussen, J. T., Andreasen, P. H., Poulsen, F. \& Kristiansen, K. (1993). The function of acyl-CoA-binding protein (ACBP)/Diazepam binding inhibitor (DBI), Molecular and Cellular Biochemistry 123, 129-138.

Kragelund, B. B., Andersen, K. V., Madsen, J. C., Knudsen, J. \& Poulsen, F. M. (1993). Three-dimensional structure of the complex between acyl-coenzyme A binding protein and palmitoyl-coenzyme A. Journal of Molecular Biology 230, 1260-1277.

Luxon, B. A. \& Weisiger, R. A. (1993). Sex differences in intracellular fatty acid transport: role of cytoplasmic binding proteins. American Journal of Physiology 265, G831-G841.

Maatman, R. G. H. J., Van Moerkerk, H. T. B., Nooren, I. M. A., Van Zoelen, E. J. J. \& Veerkamp, J. H. (1994). Expression of human liver fatty acid-binding protein in Escherichia coli and comparative analysis of its binding characteristics with muscle fatty acid-binding protein. Biochimica et Biophysica Acta 1219, 1-10. 
Madsen, P., Rasmussen, H. H., Leffers, H., Honoré, B. \& Celis, J. E. (1992). Molecular cloning and expression of a novel keratinocyte protein (Psoriasis-associated fatty acid-binding protein [PA-FABP]) that is highly up-regulated in psoriatic skin and that shares similarity to fatty acid-binding proteins. Journal of Investigative Dermatology 99, 299-305.

Malewiak, M.-I., Bass, N. M., Griglio, S. \& Ockner, R. K. (1988). Influence of genetic obesity and of fat-feeding on hepatic FABP concentration and activity. International Journal of Obesity 12, 543-546.

Melki, S. A. \& Abumrad, N. A. (1993). Expression of the adipocyte fatty acid-binding protein in streptozotocin-diabetes: effects of insulin deficiency and supplementation. Journal of Lipid Research 34, 1527-1534

Mitchell, B. D., Frazier, M. L., Kammerer, C. M., Manire, M., Harrison, C. R. \& Stern, M. P. (1993). Sib pair tests indicate linkage of insulin and $C$-peptide levels with fatty acid binding protein 2 , tyrosinase, and glucose transporter 2. American Journal of Human Genetics 53, Suppl., 835.

Nakagawa, S., Kawashima, Y., Hirose, A. \& Kozuka, H. (1994). Regulation of hepatic level of fatty-acidbinding protein by hormones and clofibric acid in the rat. Biochemical Journal 297, 581-584.

Noy, N. \& Zakim, D. (1985). Fatty acids bound to unilamellar lipid vesicles as substrates for microsomal acyl-CoA ligase. Biochemistry 24, 3521-3525.

Ockner, R. K., Burnett, D. A., Lysenko, N. \& Manning, J. A. (1979). Sex differences in long chain fatty acid utilization and fatty acid binding protein concentration in rat liver. Journal of Clinical Investigation 64, 172-181.

Paulussen, R. J. A. \& Veerkamp, J. H. (1990). Intracellular fatty-acid-binding proteins. Characteristics and function. In Intracellular Transfer of Lipid Molecules. Subcellular Biochemistry, vol. 16, pp. 175-226 [H. J. Hilderson, editor]. New York and London: Plenum Press.

Prochazka, M., Lillioja, S., Tait, J. F., Knowler, W. C., Mott, D. M., Spraul, M., Bennett, P. H. \& Bogardus, C. (1993). Linkage of chromosomal markers on $4 \mathrm{q}$ with a putative gene determining maximal insulin action in Pima Indians. Diabetes 42, 514-519.

Rasmussen, J. T., Faergeman, N. J., Kristiansen, K. \& Knudsen, J. (1994). Acyl-CoA-binding protein (ACBP) can mediate intermembrane acyl-CoA transport and donate acyl-CoA for $\beta$-oxidation and glycerolipid synthesis. Biochemical Journal 299, 165-170.

Rasmussen, J. T., Rosendal, J. \& Knudsen, J. (1993). Interaction of acyl-CoA binding protein (ACBP) on processes for which acyl-CoA is a substrate, product or inhibitor. Biochemical Journal 292, 907-913.

Rosendal, J., Ertbjerg, P. \& Knudsen, J. (1993). Characterization of ligand binding to acyl-CoA-binding protein. Biochemical Journal 290, 321-326.

Sacchettini, J. C., Gordon, J. I. \& Banaszak, L. J. (1988). The structure of crystalline Escherichia coli-derived rat intestinal fatty acid-binding protein at 2.5- $\AA$ resolution. Journal of Biological Chemistry 263, 5815-5819.

Sacchettini, J. C., Hauft, S. M., Van Camp, S. L., Cistola, D. P. \& Gordon, J. I. (1990). Developmental and structural studies of an intracellular lipid binding protein expressed in the ileal epithelium. Journal of Biological Chemistry 265, 19199-19207.

Siegenthaler, G., Hotz, R., Chatellard-Gruaz, D., Jaconi, S. \& Saurat, J.-H. (1993). Characterization and expression of a novel human fatty acid-binding protein: the epidermal type (E-FABP). Biochemical and Biophysical Research Communications 190, 482-487.

Sorrentino, D. \& Berk, P. D. (1993). Free fatty acids, albumin, and the sinusoidal plasma membrane: concepts, trends, and controversies. In Hepatic Transport and Bile Secretion: Physiology and Pathophysiology, pp. 197-210 [N. Tavoloni and P. D. Berk, editors]. New York: Raven Press, Ltd.

Spooner, P. J. R., Clark, S. B., Gantz, D. L., Hamilton, J. A. \& Small, D. M. (1988). The ionization and distribution behavior of oleic acid in chylomicrons and chylomicron-like emulsion particles and the influence of serum albumin. Journal of Biological Chemistry 263, 1444-1453.

Spooner, P. J. R., Gantz, D. L., Hamilton, J. A. \& Small, D. M. (1990). The distribution of oleic acid between chylomicron-like emulsions, phospholipid bilayers, and serum albumin. Journal of Biological Chemistry 265, 12650-12655.

Stewart, J. M., Driedzic, W. R. \& Berkelaar, J. A. M. (1991). Fatty-acid-binding protein facilitates the diffusion of oleate in a model cytosol system. Biochemical Journal 275, 569-573.

Van Breda, E., Keizer, H. A., Vork, M. M., Surtel, D. A. M., De Jong, Y. F, Van der Vusse, G. J. \& Glatz, J. F. C. (1992). Modulation of fatty-acid-binding protein content of rat heart and skeletal muscle by endurance training and testosterone treatment. Pflugers Archiv European Journal of Physiology 421, 274-279.

Van den Heuvel, J. P., Sterchele, P. F., Nesbit, D. J. \& Peterson, R. E. (1993). Coordinate induction of acyl-CoA binding protein, fatty acid binding protein and peroxisomal $\beta$-oxidation by peroxisome proliferators. Biochimica et Biophysica Acta 1177, 183-190. 
Veerkamp, J. H. \& Maatman, R. G. H. J. (1995), Cytoplasmic fatty acid-binding proteins: their structure and genes. Progress in Lipid Research 34, 17-52.

Veerkamp, J. H., Peeters, R. A. \& Maatman, R. G. H. J. (1991). Structural and functional features of different types of cytoplasmic fatty acid-binding proteins. Biochimica et Biophysica Acta 1081, 1-24.

Veerkamp, J. H., Van Kuppevelt, T. H. M. S. M., Maatman, R. G. H. J. \& Prinsen, C. F. M. (1993). Structural and functional aspects of cytosolic fatty acid-binding proteins. Prostaglandins Leukotrienes and Essential Fatty Acids 49, 887-906.

Veerkamp, J. H. \& Van Moerkerk, H. T. B. (1993). Fatty acid-binding protein and its relation to fatty acid oxidation. Molecular and Cellular Biochemistry 123, 101-106.

Vorum, H., Brodersen, R., Kragh-Hansen, U. \& Pedersen, A. O. (1992). Solubility of long-chain fatty acids in phosphate buffer at pH 7.4. Biochimica et Biophysica Acta 1126, 135-142.

Waggoner, D. W., Manning, J. A., Bass, N. M. \& Bernlohr, D. A. (1991). In situ binding of fatty acids to the liver fatty acid binding protein: analysis using 3-[125I]iodo-4-azido-N-hexadecylsalicylamide. Biochemical and Biophysical Research Communications 180, 407-415.

Weisiger, R. A. (1993). The role of albumin binding in hepatic organic anion transport. In Hepatic Transport and Bile Secretion: Physiology and Pathophysiology, pp. 171-196 [N. Tavoloni and P. D. Berk, editors]. New York: Raven Press, Ltd.

Weisiger, R. A., Pond, S. M. \& Bass, L. (1991). Hepatic uptake of protein-bound ligands: extended sinusoidal perfusion model. American Journal of Physiology 261, G872-G884.

Young, A. C. M., Scapin, G., Kromminga, A., Patel, S. B., Veerkamp, J. H. \& Sacchettini, J. C. (1994). Structural studies on human muscle fatty acid binding protein at $1.4 \AA$ resolution: binding interactions with three C18 fatty acids. Structure 2, 523-534.

Zanotti, G., Scapin, G., Spadon, P., Veerkamp, J. H. \& Sacchettini, J. C. (1992). Three-dimensional structure of recombinant human muscle fatty acid-binding protein. Journal of Biological Chemistry 267, 1854118550 . 